\title{
Grape Seed and Skin Extract Mitigates High Dosage Garlic-Induced Oxidative Stress in Rat Heart
}

\author{
Nadia LIMAM*1 $^{* 1}$ Lamjed MARZOUKI ${ }^{1}$, Mohamed AMRI ${ }^{1}$ \\ ${ }^{1}$.Neurophysiology Laboratory and Functional Pathology, Department of Biological Sciences, Faculty of \\ Sciences of Tunis, University Campus of Al-Manar II-2092, Tunis.
}

${ }^{*}$ Corresponding author: E-mail: limam.nadia@live.fr

\begin{abstract}
Garlic is a commonly used spice in folk medicine which could exert adverse health effects when given at high dose. Grape seed and skin extract (GSSE) exhibits a variety of beneficial effects even at high dose. In the present study we evaluated the toxicity of high garlic dose treatment on heart and the protective effect of GSSE. Rats were intraperitoneally (IP) administered either with garlic extract $(5 \mathrm{~g} / \mathrm{kg} \mathrm{bw})$ or GSSE $(500 \mathrm{mg} / \mathrm{kg} \mathrm{bw})$ or a combination of garlic and GSSE at the same doses daily for one month. Data showed that high garlic dose induced heart toxicity and a pro-oxidative status characterized by increased MDA, NO, carbonyl protein, $\mathrm{LDH}, \mathrm{H}_{2} \mathrm{O}_{2}$, free iron, and calcium. Unexpectedly garlic increased catalase and peroxidase but had no effect on superoxide dismutase. GSSE alone or in co-treatment with garlic had an opposite role and counteracted almost all garlic-induced deleterious effects to near control level. In conclusion, high garlic dose induced a pro-oxidative state into heart via the Fenton reaction between $\mathrm{H}_{2} \mathrm{O}_{2}$ and free iron, and GSSE exerted antioxidant properties.
\end{abstract}

\section{Indexing terms/Keywords}

Garlic; Grape seed and skin extract; Heart; redox status; antioxidant enzymes.

\section{Council for Innovative Research}

Peer Review Research Publishing System

\section{Journal: Journal of Advances in Chemistry}

Vol. 10, No. 3

editorjaconline@gmail.com

www.cirjac.com 


\section{INTRODUCTION}

Garlic (Allium sativum L.) has been widely used as a flavoring compound and in traditional medicine as a healing agent. Health effects of garlic extract were mainly attributable to organosulfur compounds and to a lesser extent to flavonoids and phenolics [1]. Allicin (allyl-2-propenethiosulfinate) exhibited antibacterial and anticancer activity by inducing apoptosis in a caspase -3- dependent way [2]. Diallyl monosulfide (DAMS) and diallyl-trisulfide (DATS) exhibited antioxidant activity in vivo and in vitro [3] whereas diallyl-disulfide (DADS) and S-allyl-L-cysteine sulfoxide (SACS) improved heart activity and hyperlipidemia [4]. Recently thiacremonone a novel sulfur compound isolated from garlic was shown to exert antiinflammatory properties [5]. Flavonoids and phenolic compounds have been implicated in anticancer activities of fresh garlic [1]. However some controversies persist concerning garlic dose or mode of administration. In prior studies, we showed that high garlic dose administered IP induced a pro-oxidative state into the blood compartment [6], the brain [7], the heart [8], the kidney [9], the liver and the spleen [10].

Grape seed and skin extract (GSSE) is a nutritional supplement exhibiting beneficial health effects. GSSE is a complex mixture of polyphenolics classified as flavonoid and non flavonoid compounds [11]. Flavonoids which are highly concentrated in grape seeds are mainly composed of monomeric catechins, proanthocyanidins and flavonols as quercetin [12]. Non-flavonoids, highly present in grape skin, contained stilbenes as resveratrol which is at the basis of the French Paradox [12].

GSSE had wide-ranging benefits, including renoprotective [13] and neuroprotective [14] properties. GSSE also protected against hepatic ischemia-reperfusion injury [15]. Resveratrol exerted multi-organ protective effects owing to its antioxidant versant [16], and proanthocyanidins exerted antineoplasic effects by inducing cytotoxicity towards some cancer cells, by cell cycle arrest and induction of apoptosis [17]. In addition quercetin and rutin were neuroprotective [18] and catechin, epicatechin and gallic acid exhibited cholesterol-lowering activity [19].

The present study was designed to evaluate the toxic effect of high dosage garlic when administered IP on Heart antioxidant status, as well as the putative protection offered by GSSE treatment. Our data confirmed the pro-oxidant effect of high garlic dose and provide new data on the protection offered by GSSE.

\section{EXPERIMENTAL}

\section{Chemicals}

Thiobarbituric acid (TBA); 2,6,-di-tert-butyl-4-hydroxy-toluene (BHT); trichloroacetic acid (TCA); hydrogen peroxide $\left(\mathrm{H}_{2} \mathrm{O}_{2}\right)$; 2-methoxyphenol (gaiacol); bovine catalase and 4-(1-Hydroxy-2-methylamino-ethyl)-benzene-1,2-diol (epinephrine), 2,4,dinitrophenyl hydrazine (DNPH) were obtained from Sigma-Aldrich Co (Germany).

\section{Preparation of garlic and grape seed and skin extracts}

One kilogram garlic (Allium sativum L.) was purchased from local market, peeled and grounded during 30 min with an electric mincer (FP3121 Moulinex) until an aqueous suspension was obtained. It was diluted in double distilled water at 4 $\mathrm{g} / \mathrm{ml}$ on the basis of the weight of the starting material and centrifuged (Beckman J20, 15 min at $10000 \mathrm{~g}$ and $4^{\circ} \mathrm{C}$ ). Supernatant was aliquoted and stored at $-80^{\circ} \mathrm{C}$ until use.

GSSE was processed from a grape cultivar (Carignan) of Vitis vinifera from northern Tunisia. Waste from winemaking was collected from Tardi Cooperative Winery (Ain Ghelal). Seeds and skin were dried and ground separately with an electric mincer (FP3121 Moulinex) until a fine powder was obtained. Total phenolic content was determined by the folin-Ciocalteau colorimetric method [20], flavonoids and condensed tannins according to [21] and [22] respectively (Table I). Powder mixture containing grape seed (50\%) and skin (50\%) was dissolved in $1 \mathrm{~mL}$ of $10 \%$ ethanol in the dark, vigorously vortexed for $10 \mathrm{~min}$, centrifuged at $10000 \mathrm{~g}$ for $15 \mathrm{~min}$ at $4^{\circ} \mathrm{C}$ for debris elimination and the supernatant containing soluble polyphenols was used.

\section{Animals and treatment}

Fourty male Wistar rats (200-240 g) from Pasteur Institute of Tunis were used for these experiments in accordance with the local ethic committee of Tunis University and care of animals in conformity with the NIH recommendations [23]. They were provided with food and water ad libitum and maintained in animal house at controlled temperature $\left(22 \pm 2^{\circ} \mathrm{C}\right)$ with a $12 \mathrm{~h}$ light-dark cycle. Rats were divided into four groups of ten animals each. Group I received ethanol 10\% (control), group II aqueous extract of garlic (5 g/kg bw), group III GSSE $(500 \mathrm{mg} / \mathrm{kg} \mathrm{bw})$ and group IV garlic plus GSSE. Animals were daily administered IP during 30 days. Twenty-four hours after the last injection, animals were sacrificed, their heart rapidly excised and homogenized in phosphate buffer saline $\mathrm{pH} 7.4$ with an ultrathurax T25 homogenisator. After centrifugation at $10000 \mathrm{~g}$ for $10 \mathrm{~min}$ at $4^{\circ} \mathrm{C}$, supernatant was used for the determination of lipoperoxidation, carbonylation, antioxidant enzyme activities and intracellular mediators as free iron, $\mathrm{H}_{2} \mathrm{O}_{2}, \mathrm{NO}$ and calcium. Blood was also collected and plasma processed for LDH determination.

\section{Lipoperoxidation determination}

Lipid peroxidation was assessed by MDA measurement according to the double heating method [24]. Briefly, aliquots (200 $\mu \mathrm{l})$ from heart homogenates were mixed with $250 \mu \mathrm{l} \mathrm{BHT-TCA}$ solution containing $1 \% \mathrm{BHT}(\mathrm{w} / \mathrm{v})$ dissolved in $20 \%$ TCA $(\mathrm{w} / \mathrm{v})$ and centrifuged at $1000 \mathrm{~g}$ for $5 \mathrm{~min}$ at $4^{\circ} \mathrm{C}$. Supernatant $(400 \mu \mathrm{l})$ was blended with $0.5 \mathrm{~N} \mathrm{HCl}(80 \mu \mathrm{l}), 120 \mathrm{mM}$ TBA in $26 \mathrm{mM}$ Tris $(320 \mu \mathrm{l})$ and then heated at $80^{\circ} \mathrm{C}$ for $10 \mathrm{~min}$. After cooling, absorbance of the resulting pink chromophore was 
determined at $532 \mathrm{~nm}$ using a SmartSpec 3000 BIORAD UV-visible spectrophotometer (Germany). MDA levels were determined by using an extinction coefficient for MDA-TBA complex of $1.5610^{5} \mathrm{M}^{-1} \mathrm{~cm}^{-1}$.

\section{Protein carbonylation}

Oxidative damage to proteins was evaluated by quantifying protein carbonylation in heart homogenates according to [25]. After proteins precipitation with $20 \%$ TCA and centrifugation at $10000 \mathrm{~g}$ for 3 min at $4^{\circ} \mathrm{C}$ (Beckman J20), pellet was dissolved in $10 \mathrm{mM}$ DNPH-containing buffer. After 3 washings with ethanol-ethylacetate (1:1), pellet was dissolved in 20 $\mathrm{mM}$ potassium phosphate $(\mathrm{pH} 2.3)$ containing $6 \mathrm{M}$ guanidine $\mathrm{HCl}$ and absorbance measured at $366 \mathrm{~nm}$ using the molar extinction coefficient of $22000 \mathrm{M}^{-1} \mathrm{~cm}^{-1}$. Results were expressed as nmol carbonyl residues/mg protein.

\section{Protein determination}

Total soluble proteins were determined according to the Biuret method [26]. Briefly, at acidic pH soluble proteins constituted with copper a colourful complex measurable at $546 \mathrm{~nm}$ using a SmartSpec 3000 BIORAD UV-visible spectrophotometer (Germany).

\section{LDH determination}

Lactate dehydrogenase activity was determined using a commercially available kit from Biomaghreb (Tunisia) [27]. Briefly, heart homogenate was added to reaction mixture containing NADH and (80 mM) tris buffer pH 7.2. LDH activity was assayed by measuring the initial rate of NADH disappearance at $340 \mathrm{~nm}$.

\section{Antioxidant enzyme activity assays}

All spectrophotometric analyses of heart antioxidant enzyme activities were performed with a SmartSpec 3000 BIORAD UV-visible spectrophotometer (Germany).

Catalase (CAT): CAT activity was assayed by measuring the initial rate of $\mathrm{H}_{2} \mathrm{O}_{2}$ disappearance at $240 \mathrm{~nm}$ [28]. The reaction mixture contained $33 \mathrm{mM}(1000 \mu \mathrm{l}) \mathrm{H}_{2} \mathrm{O}_{2}$ in $50 \mathrm{mM}(1995 \mu \mathrm{l})$ phosphate buffer $\mathrm{pH} 7.0$ and $5 \mu$ l of heart extract. CAT activity was calculated using the extinction coefficient of $40 \mathrm{mM}^{-1} \mathrm{~cm}^{-1}$ for $\mathrm{H}_{2} \mathrm{O}_{2}$.

Peroxidase $(P O D)$ : POD activity was measured at $25^{\circ} \mathrm{C}$ using guaiacol as hydrogen donor. The reaction mixture contained $9 \mathrm{mM}(25 \mu \mathrm{l})$ guaiacol, $19 \mathrm{mM}(100 \mu \mathrm{l}) \mathrm{H}_{2} \mathrm{O}_{2}$ in $50 \mathrm{mM}(870 \mu \mathrm{l})$ phosphate buffer $\mathrm{pH} 7$ and $5 \mu \mathrm{l}$ of heart extract in $1 \mathrm{ml}$ final volume. The reaction was initiated by the addition of $\mathrm{H}_{2} \mathrm{O}_{2}$ and monitored by measuring the increase in absorbance at $470 \mathrm{~nm}$ each $30 \mathrm{~s}$ for $3 \mathrm{~min}$. Peroxidase activity was expressed as nmol of guaiacol oxidized per min with a molecular extinction coefficient of $26.2 \mathrm{mM}^{-1}$ for calculation [29].

Superoxide dismutase (SOD): SOD activity was determined by using modified epinephrine assay [30]. At alkaline $\mathrm{pH}$, superoxide anion $\left(\mathrm{O}_{2}^{-}\right)$causes the auto-oxidation of epinephrine to adenochrome. One unit of SOD is defined as the amount of extract that inhibits the rate of adenochrome formation by $50 \%$. Heart extract was added in $2 \mathrm{ml}$ reaction mixture containing $10 \mu \mathrm{l}$ bovine catalase $(0.4 \mathrm{U} / \mu \mathrm{l}), 20 \mu \mathrm{l}$ epinephrine $(5 \mathrm{mg} / \mathrm{ml})$ and $62.5 \mathrm{mM}$ sodium carbonate/sodium bicarbonate buffer $\mathrm{pH}$ 10.2. Changes in absorbance were recorded at $480 \mathrm{~nm}$. Characterization of SOD isoforms was performed using KCN (3 mM) which inhibited Cu/Zn-SOD or $\mathrm{H}_{2} \mathrm{O}_{2}(5 \mathrm{mM})$ affecting both $\mathrm{Cu} / \mathrm{Zn}-\mathrm{SOD}$ and Fe-SOD. MnSOD was insensitive to both inhibitors.

\section{Free iron determination}

Free iron was determined according to [31] using a commercially available kit from Biomaghreb. Briefly, at acidic $\mathrm{pH} 4.8$ all $\mathrm{Fe}^{3+}$ released from transferrine was reduced by ascorbic acid into $\mathrm{Fe}^{2+}$, which constituted with ferrozine a purple colourful complex measurable at $560 \mathrm{~nm}$. $50 \mu \mathrm{l}$ of heart extract was added to $250 \mu \mathrm{l}$ of reaction mixture containing ascorbic acid (5 $\mathrm{g} / \mathrm{L})$ and ferrozin $(40 \mathrm{mM})$ and incubation performed at $37^{\circ} \mathrm{C}$ during $10 \mathrm{~min}$

\section{$\mathrm{H}_{2} \mathrm{O}_{2}$ determination}

$\mathrm{H}_{2} \mathrm{O}_{2}$ level was determined enzymatically according to [32] using a commercially available kit from Biomaghreb. Briefly, in the presence of peroxidase, $\mathrm{H}_{2} \mathrm{O}_{2}$ reacts with 4-amino-antipyrine and phenol to give a red colored quinoeimine which absorbed at $505 \mathrm{~nm}$. Results are expressed as $\mathrm{mmol} \mathrm{H}_{2} \mathrm{O}_{2} / \mathrm{mg}$ protein.

\section{Calcium measurement}

Ionizable calcium was determined according to [33] using a commercially available kit from Biomaghreb. At basic pH calcium constituted with cresolphtalein a purple colourful complex measurable at $570 \mathrm{~nm}$. Briefly, $50 \mu \mathrm{l}$ of heart extract was added to $650 \mu \mathrm{l}$ of reaction mixture containing 2-amino-2-methyl 1-propanol buffer (500 mmol/L), cresolphtalein $(0.62$ $\mathrm{mmol} / \mathrm{L})$ and hydroxy-8 quinoleine $(69 \mathrm{mmol} / \mathrm{L})$. Incubation was carried out at room temperature for 5 min assuming the complex was stable for 1 hour.

\section{NO metabolites measurement}

NO was measured by quantification of nitrite and nitrate, determined colorimetrically using a commercially available kit from Roche Diagnostics France, according to Green et al., [34]. 


\section{Statistical analysis}

Data were analyzed by unpaired Student's t-test or one-way analysis of variance (ANOVA) and expressed as means \pm standard error of the mean (SEM). All statistical tests were two-tailed and results with $p<0.05$ were considered significant.

\section{RESULTS AND DISCUSSIONS}

\section{Results}

We reported in Figure 1 the effect of garlic and GSSE either alone or in combination on lipoperoxidation (Figure 1A), carbonylation (Figure 1B) and LDH (Figure 1C). As expected, garlic increased MDA (+ 600\%), carbonyl protein (+ 86\%) and LDH (+ 88\%) whereas GSSE, which had no significant effect per se, counteracted all garlic-induced deleterious effect regarding to these parameters.

Figure 2 showed that garlic had no effect on POD (Figure 2B) but increased CAT by 160\% (Figure 2A) and SOD by $13 \%$ (Figure $2 \mathrm{C}$ ). In this latter case, garlic mainly increased the iron and to a lesser extent the Mn isoform. GSSE per se clearly decreased POD (- 27\%), increased CAT $(+76 \%)$ and SOD (+ $67 \%)$ activities; in this latter case, GSSE mainly increased the iron and to a lesser extent the Mn isoform. Treatment with GSSE abrogated all garlic-induced effects on antioxidant enzyme activities.

We further sought to determine the putative involvement of intra-cardiac mediators in garlic and GSSE mode of action (Figure 3). Garlic increased free iron (+136\%) (Figure 3A), $\mathrm{H}_{2} \mathrm{O}_{2}(+144 \%)$ (Figure 3B), calcium (+ 110\%) (Figure 3C) and $\mathrm{NO}\left(+320 \%\right.$ ) (Figure 3D). GSSE per se had no effect on $\mathrm{NO}$ nor calcium, decreased $\mathrm{H}_{2} \mathrm{O}_{2}$ and increased free iron levels. Co-treatment with GSSE abrogated all garlic-induced disturbances of all intracellular mediators to near control level.

\section{Discussions}

The present study revealed that a high dosage garlic administered by IP way to rats for 1 month resulted in heart injury as evidenced by increased lipoperoxidation and carbonylation. Heart toxicity was also reflected by elevated LDH, and a concomitant increase in free iron, $\mathrm{H}_{2} \mathrm{O}_{2}$, calcium and NO. Paradoxically the positive effect of garlic on CAT and SOD activities might represent a "pro-oxidative state" in light of the unexpected and previously described pro-oxidant effect of CAT [35] or SOD [36]. In addition post-translational modifications of antioxidant enzymes and the subsequent gain in activity could also be involved [37].

Furthermore our data showed that treatment with GSSE for one month reduced garlic-induced cardiotoxicity and oxidative stress. First GSSE was used at a dosage previously shown to be devoid of any toxicity. Our data corroborated a tremendous literature dealing with antioxidant and anti-inflammatory effects of GSSE that have been observed either in vitro or in vivo and in various experimental settings [38].

Our data gave some new insight into garlic as well as GSSE mode of action. Garlic simultaneously increased free iron and $\mathrm{H}_{2} \mathrm{O}_{2}$ within heart tissue, likely leading to the highly toxic hydroxyl radical via the Fenton reaction and ultimately to cardiotoxicity. Increased MDA level is known to cause a decrease in the fluidity of the membrane lipid bilayer [39] and high MDA level is generally correlated to pathological or stress conditions including aging [40]. Moreover, garlic increased intracellular calcium, which is likely linked to its effect on $\mathrm{H}_{2} \mathrm{O}_{2}$ elevation and high $\mathrm{NO}$ level. In this latter case garlic could act by enhancing hydrogen sulphide production [41] which in turn phosphorylated eNOS to activate this enzyme and increase NO bioavailability [42].

Garlic mainly contained organosulfur compounds as allicin, ajoene, diallyl disulfide (DADS), diallyl trisulfide (DATS), S-allyl cysteine (SAC), S-allyl cysteine sulfoxide (SACS), and flavonoids, phenolics and anthocyanins [1]. The effect of garlic on heart could also result from synergism or antagonism between the various bioactive components of the mixture, and high range organosulfurs are at the basis of the pro-oxidative effect of crude garlic [43].

To our knowledge our report is the first one to show that GSSE is protective against garlic-induced oxidative stress into the heart, as it attenuated garlic-induced toxicity, oxidative stress and calcium elevation. GSSE was used at a high dosage $(500 \mathrm{mg} / \mathrm{kg} \mathrm{bw})$ that was safe and near the optimal concentration precognized by Hebbar et al. [44]. GSSE was also tested at wide ranging doses reaching $4 \mathrm{~g} / \mathrm{kg} b w$ with no sign of toxicity even at the morphological level (not shown). GSSE has been previously shown to protect multiple target organs from doxorubicin [45] and from garlic-induced toxicity owing to its antioxidant [46-48] and antiapoptotic properties [49]. In this respect, it has been shown that pre-treatment of gastric epithelial cells with red wine prevented from xanthine induced oxidative stress cell damage [50], and that grape seed extract protected the skin from damages induced by UV radiations [51].

The suppressive effect of GSSE on NO production seems to be linked to its antioxidant activity. In fact, GSSE counteracted garlic-induced increase in $\mathrm{H}_{2} \mathrm{O}_{2}$, free iron and markedly attenuated calcium elevation. These effects could be mediated by ROS scavenging activity of GSSE as demonstrated for resveratrol [52]. Consumption of GSSE is protective against cardiovascular diseases in humans [53]. A possible mechanism by which GSSE exerts its beneficial effect on heart is its ability to chelate free iron and scavenge $\mathrm{H}_{2} \mathrm{O}_{2}$ as recently demonstrated by some of us [54]. Free iron is a well established catalyst of auto-oxidation and iron-mediated oxidations of cysteine residues represent a common mechanism through which $\mathrm{H}_{2} \mathrm{O}_{2}$ exerts its second messenger role in signal transduction pathways [55]. Further studies should also analyze the implication of specific proteins involved in free iron metabolism as hepcidin [56]. Moreover, $\mathrm{H}_{2} \mathrm{O}_{2}$ is able to induce dual roles in both survival and cell death pathways, largely depending on its concentration and also on the cell type. In this 
respect, one mechanism by which $\mathrm{H}_{2} \mathrm{O}_{2}$ exerted its prolongevity effect in several species including rat involves $\mathrm{H}_{2} \mathrm{O}_{2}$ induction of SOD activity [57].

We do not yet know which active compounds present in GSSE extract are responsible for the observed protection. GSSE is a complex mixture of polyphenolics classified as flavonoid and non flavonoid compounds [11]. Flavonoids are mainly composed of monomeric catechins, proanthocyanidins and flavonols such as quercetin [12]. Non-flavonoids contain stilbenes such as resveratrol, which is at the basis of the French paradox [12]. GSSE composition is complex and a synergism likely occurs between skin-containing polyphenols and seeds-containing fatty acids as recently described for magnolias seeds [58].

However our results also raised several discrepancies. In particular garlic appeared in the same time as pro-oxidant owing to its effect on increased MDA, carbonyl protein, $\mathrm{NO}$, calcium, free iron and $\mathrm{H}_{2} \mathrm{O}_{2}$ and also antioxidant as it increased CAT and SOD activities. In this latter case, garlic up-regulated mainly the iron and to a lesser extent the Mn isoform. Although preliminary, our data are reminiscent of those described by Borchi et al., [37] obtained on human failing heart. This apparent discrepancy is reminiscent of the paradoxal pro-oxidant effect of catalase [35] which should be interpreted in the light of oxidative stress-induced ROS activation of non receptor tyrosine kinases associated with CAT phosphorylation and gain activity [37]. In this later case, increased CAT and GPx activities were solely due to elevated tyrosine phosphorylation. In our present case, high dosage garlic could provoke up-phosphorylation of CAT and SOD activities witout affecting POD. In relation to GSSE, it could induce phosphorylation of Fe-SOD and $\mathrm{Mn}$ isoforms and by this way enhanced their activities without modifying their expression nor abundance. However, transcriptional control by GSSE of SOD1 and GPx1 expression could not be excluded [59].

In conclusion, high dosage garlic induced cardiotoxicity in relation to its pro-oxidative properties and GSSE exerted cardioprotective effect partly by an antioxidant way.

\section{REFERENCES}

[1] Shirzad, H., Taji, F., Rafieian-Kopaei, M. 2011. Correlation between antioxidant activity of garlic extracts and WEHI-164 fibrosarcoma tumor growth in BALB/c mice. J Med Food. 14(9), 969-974.

[2] Padilla-Camberos, E., Zaitseva, G., Padilla, C., Puebla, A.M. 2010. Antitumoral activity of allicin in murine lymphoma L5178Y. Asian Pac J Cancer Prev. 11(5), 1241-1244.

[3] Ponnusamy, M., Pari, L. 2011. Protective role of diallyl tetrasulfide on cadmium-induced testicular damage in adult rats: a biochemical and histological study. Toxicol. Ind. Health. 27(5), 407-416.

[4] Asdaq, S.M., Inamdar, M.N. 2010. Potential of garlic and its active constituent, S-allyl cysteine, as antihypertensive and cardioprotective in presence of captopril. Phytomed. 17(13), 1016-1026.

[5] Ban, J., Oh, J., Kim, T., Kim, D.J.,Jeong, H.S., Han, S.B., Hong, J.T. $2009 . \quad$ Antiinflammatory and arthritic effects of thiacremonone, a novel sulfur compound isolated from garlic via inhibition of NFkappaB. Arthritis Res Ther. 11(5), R145.

[6] Hamlaoui-Gasmi, S., Mokni, M., Limam, F., Aouani, E., Amri, M., Marzouki, L. 2011. Effect of the route of garlic treatment on modulation of erythrocytes and plasma redox status in rats. J. Med. Plants Research. 5(12), 2508-2513.

[7] Hamlaoui, S., Limam, N., Mokni, M., Limam, F., Aouani, E., Amri, A., Marzouki, L. 2011b. Garlic mode treatment effects on rat brain redox status. J. Med. Plants Research. 5(20), 5094-5098.

[8] Hamlaoui-Gasmi, S., Limam, N., Mokni, M., Limam, F., Aouani, E., Amri, M., Marzouki, L. 2012. Modulation of heart redox status by garlic based on route of administration in rat. Afr. J. Biotech. 11(4), 912-918.

[9] Hamlaoui, S., Samti, O., Mokni, M., Limam, N., Limam, F., Aouani, E., Amri, M., Marzouki, L. 2012a. Modulation of renal redox status by garlic based on route of administration in rat. Afr. J. Pharm. Pharmacol. 6(25), 1843-1849.

[10] Hamlaoui-Gasmi, S., Mokni, M., Limam, N., Limam, F., Aouani, E., Amri, M., Marzouki, L. 2011c. Effect of the route of garlic treatment on modulation of liver and spleen redox status in rats. J. Med. Plants Research. 5(15), 3466-3474.

[11] Khanal, R.C., Howard, L.R., Prior, R.L. 2009. Procyanidin content of grape seed and pomace, and total anthocyanin content of grape pomace as affected by extrusion processing. J. Food Sci. 74(6), H174-H182.

[12] Renaud, S., De Lorgeril, M. 1992. Wine, alcohol, platelets, and the French paradox for coronary heart disease. Lancet. 339(8808), 1523-1526.

[13] Safa, J., Argani, H., Bastani, B., Nezami, N., Ardebili, B.R., Ghorbanihaghjo, A. 2010. Protective Effect of Grape Seed Extract on Gentamicin-Induced Acute Kidney Injury. Iran J Kid Diseases. 4, 285-291.

[14] Wang, Y.J., Thomas, P., Zhong, J.H., Bi, F.F., Kosaraju, S., Pollard, A., Fenech, M., Zhou, X.F. 2009. Consumption of grape seed extract prevents amyloïd- $\beta$ deposition and attenuates inflammation in brain of an Alzheimer's disease mouse. Neurotox Res. 15, 3-14.

[15] Sehirli, O., Ozel, Y., Dulundu, E., Topaloglu, U., Ercan, F., Sener, G. 2008. Grape seed extract treatment reduces hepatic ischemia-reperfusion injury in rats. Phytother Res. 22, 43-48. 
[16] Hamlaoui, S., Mokni, M., Limam, N., Carrier, A., Limam, F., Amri, M., Marzouki, L., Aouani, E. 2012b. Resveratrol protects against acute chemotherapy toxicity induced by doxorubicin in rat erythrocyte and plasma. J. Physiol Pharmacol. 63(3), 293-301.

[17] Kaur, M., Mandair, R., Agarwal, R., Agarwal, C. 2008. Grape seed extract induces cell cycle arrest and apoptosis in human colon carcinoma cells. Nutr Cancer. 60, 2-11.

[18] Jiménez-Aliaga, K., Bermejo-Bescós, P., Benedí, J., Martín-Aragón, S. 2011. Quercetin and rutin exhibit antiamyloidogenic and fibril-disaggregating effects in vitro and potent antioxidant activity in APPswe cells. Life Sci. 89(25-26), 939-945.

[19] Ngamukote, S., Mäkynen, K., Thilawech, T., Adisakwattana, S. 2011. Cholesterol-lowering activity of the major polyphenols in grape seed. Molecules. 16(6), 5054-5061.

[20] Singleton, V.L., Rossi, J.A. 1965. Colorimetry of total phenolic with phosphomolybdic phosphotungstic acid reagent. Am. J. Enol. Vitic. 16, 144-158.

[21] Dewanto, V., Wu, X., Adom, K.K., Liu, R.H. 2002. Thermal processing enhances the nutritional value of tomatoes by increasing total antioxidant activity. J. Agric. Food Chem. 50(10), 3010-3014.

[22] Sun, B.S., Ricardo-Da-Silva, J.M., Spranger, M.I. 1998. Critical factors of vanillin assay for catechins and proanthocyanidins. J. Agric. Food. Chem. 46(10), 4267-4274.

[23] Guide for the Care and the Use of Laboratory Animals. 1996. National Research Council. Washington D.C: National Academy Press.

[24] Draper, H.H., Hadley, M. 1990. Malondialdehyde determination as index of lipid peroxidation. Methods Enzymol. 86, 421-431.

[25] Levine, L.R., Garland, D., Oliver, C.N., Amici, A., Climent, I., Lenz, A.G., Ahn, B.W., Shaltiel, S., Stadtman, E.R. 1990. Determination of carbonyl content in oxidatively modified proteins. Methods Enzymol. 186, 464-478.

[26] Ohnishi, S.T., Barr, J.K.. 1978. A simple method of quantitating protein using the biuret and phenol reagent. Anal Biochem. 86, 193-200.

[27] Bergmeyer, H.U. 1975. New values for the molar extinction coefficients of NADH and NADPH for the use in routine laboratories (author's transl). Z Klin. Chem. Klin. Biochem. 13(11), 507-508.

[28] Aebi, H. 1984. Catalase in vitro. Methods Enzymol. 105, 121-126.

[29] Chance, B., Maehly, A.C.. 1955. Assay of catalases and peroxidases. Methods Enzymol. 2, 764-817.

[30] Misra, H.P., Fridovich, I. 1972. The role of superoxide anion in autoxidation of epinephrine and a simple assay for SOD. J. Biol. Chem. 247, 3170-3175.

[31] Leardi, A., Caraglia, M., Selleri, C., Pepe, S., Pizzi, C., Notaro, R., Fabbrocini, A., De Lorenzo, S., Musicò, M., Abbruzzese, A., Bianco, A.R., Tagliaferri, P. 1998. Desferioxamine increases iron depletion and apoptosis induced by ara-C of human myeloid leukaemic cells. Bri.t J. Haematol. 02, 746-752.

[32] Kakinuma, K., Yamaguchi, T., Kaneda, M., Shimada, K., Tomita, Y., Chance, B. 1979. A determination of $\mathrm{H}_{2} \mathrm{O}_{2}$ release by the treatment of human blood polymorphonuclear leukocytes with myristate. J. Biochem. 86(1), 87-95.

[33] Stern, J., Lewis, W.H. 1957. Clin. Chim. Acta. 2, 576-580.

[34] Green, L.C., Wagner, D.A., Glogowski, J., Skipper, P.L., Wishnok, J.S., Tannenbaum, S.R. 1982. Anal. Biochem. 126,131-138.

[35] Heck, D.E., Vetrano, A.M., Mariano, T.M., Laskin, J.D. 2003. UVB light stimulates production of reactive oxygen species. Unexpected role of catalase. J. Biol. Chem. 278, 2243-2246.

[36] Golsteins, G., Keksa-Golsteine, V., Ahtoniemi, T., Jaronen, M., Arens, E., Akerman, K., Chan, P.H., Koistinaho, J. 2008. Deleterious role of superoxide dismutase in the mitochondrial intermembrane space. J. Biol. Chem. 283, 84468452.

[37] Borchi, E., Bargelli, V., Stillitano, F., Giordano, C., Sebastiani, M., Nassi, P.A., D'amati, G., Cerbai, E., Nediani, C. 2010. Enhanced ROS production By NADPH oxidase is correlated to changes in antioxidant enzyme activity in human heart failure. Biochim. Biophys. Acta. 1802(3), 331-8.

[38] Nassiri-Asl, M., Hosseinzadeh, H. 2009. Review of the pharmacological effects of Vitis vinifera (Grape) and its bioactive compounds. Phytother Res. 23, 1197-1204.

[39] Bryszewska, M., Zavodnik, I.B., Niekurzak, A., Szosland, K. 1995. Oxidative processes in red blood cells from normal and diabetic individuals. Biochem. Mol. Biol. Int. 37, 345-354.

[40] Rizvi, S.I., Maurya, P.K.. 2007. Markers of oxidative stress in erythrocytes during aging in humans. Ann. N.Y. Acad. Sci. 1100, 373-382. 
[41] Benavides, G.A., Squadrito, G.L., Mills, R.W., Patel, H.D., Isbell, T.S., Patel, R.P., Darley-Usmar, V.M., Doeller, J.E., Kraus, D.W. 2007. Hydrogen sulfide mediates the vasoactivity of garlic. Proc. Natl. Acad. Sci.104(46), 17977-82.

[42] Khatua, T.N., Padiya, R., Karnewar, S., Kuncha, M., Agawane, S.B., Kotamraju, S., Banerjee, S.K.. 2012. Garlic provides protection to mice heart against isoproterenol-induced oxidative damage: Role of nitric oxide: Nitric Oxide. 27, 9-17.

[43] Oboh, G. 2009. Tropical green leafy vegetables prevent garlicinduced hepatotoxicity in the rat. J. Med. Food. 9(4), $545-551$.

[44] Hebbar, V., Shen, G., Hu, R., Kim, B.R., Chen, C., Korytko, P.J., Crowell, J.A., Levine, B.S., Kong, A.N.. 2005. Toxicogenomics of resveratrol in rat liver. Life Sci. 76, 2299-2314.

[45] Hamlaoui, S., Mokni, M., Limam, N., Carrier, A., Limam, F., Amri, M., Marzouki, L., Aouani, E. 2012c. Grape seed and skin extract protects against acute chemotherapy toxicity induced by doxorubicin in rat red blood cells and plasma. Banglad J. Pharmacol. 7, 54-62.

[46] Hamlaoui-Gasmi, S., Mokni, M., Limam, N., N'guessan, P., Carrier, A., Limam, F., Amri, M., Aouani, E., Marzouki, L. 2012. Grape seed and skin extract mitigates garlic-induced oxidative stress in rat liver. Can. J. Pharm. Pharmacol. 90, 1-10.

[47] Hamlaoui, S., Mokni, M., Limam, N., Zouaoui, K., Ben Rayana, M.C., Carrier, A., Limam, F., Amri, M., Marzouki, L., Aouani, E. 2012d. Protective effect of grape seed and skin extract on garlic induced erythrocyte oxidative stress. J. Physiol. Pharmacol. 63(4), 381-388.

[48] Hamlaoui, S., Samti, O., Mokni, M., Limam, N., Carrier, A., Limam, F., Aouani, E., Marzouki, L. 2012e. Protective effect of grape seed and skin extract on high dosage garlic-induced renal oxidative stress. Banglad J. Pharmacol. 7, 77-86.

[49] Bagchi, D., Sen, C.K., Ray, S.D., Das, D.K., Bagchi, M., Preuss, H.G., Vinson, J.A. 2003. Molecular mechanisms of cardioprotection by a novel grape seed proanthocyanidin extract. Mutat. Res. 523, 87-97.

[50] Loguercio, C., Tuccillo, C., Fererico, A., Fogliano, V., Del Vecchio Blanco, C., Romano, M. 2009. Alcoholic beverages and gastric epithelial cell viability: effect on oxidative stress induced damage. J. Physiol. Pharmacol. 60, 87-92.

[51] Filip, A., Clichici, S., Daicoviciu, D., Catoi, C., Bolfa, P., Postescu, I.D., Gal, A., Baldea, I., Gherman, C., Muresan, A. 2011. Chemopreventive effects of Calluna vulgaris and Vitis vinifera extracts on UVB-induced skin damage in SKH-1 hairless mice. J. Physiol. Pharmacol. 62, 385-392.

[52] Leonard, S.S., Xia, C., Jiang, B.H., Stinefelt, B., Klandorf, H., Harris, G.K., Shi, X. 2003. Resveratrol scavenges reactive oxygen species and affects radical-induced cellular responses. Biochem. Biophys. Res. Comm. 309, 10171026.

[53] Das, D.K., Maulik, N. 2006. Resveratrol in cardioprotection: a therapeutic promise of alternative medicine. Mol. Interv. 6(1), 36-47.

[54] Charradi, K., Sebai, H., Elkahoui, S., Ben Hassine, F., Limam, F., Aouani, E. 2011. Grape seed extract alleviates highfat diet-induced obesity and heart dysfunction by preventing cardiac siderosis. Cardiovasc Toxicol. 11, 28-37.

[55] Barbouti, A., Amorgianiotis, C., Kolettas, E., Kanavaros, P., Galaris, D. 2007. Hydrogen peroxide inhibits caspasedependent apoptosis by inactivating procaspase-9 in an iron-dependent manner. Free Radic. Biol. Med. 43, $1377-87$.

[56] Isoda, M., Hanawa, H., Watanabe, R., Yoshida, T., Toba, K., Yoshida, K., Kojima, M., Otaki, K., Hao, K., Ding, L., Tanaka, K., Takayama, T., Kato, K., Okura, Y., Kodama, M., Ota, Y., Hayashi, J., Aizawa, Y. 2010. Expression of the peptide hormone hepcidin increases in cardiomyocytes under myocarditis and myocardial infarction. J. Nutr. Biochem. 21, 749-756.

[57] Yoshioka, T., Homma, T., Meyrick, B., Takeda, M., Moore-Jarrett, T., Kon, V., Ichikawa, I. 1994. Oxidants induce transcriptional activation of manganese superoxide dismutase in glomerular cells. Kidney Int. 46, 405-413.

[58] Park, K.H., Kim, S.Y., Gul, R., Kim, B.J., Jang, K.Y., Chung, H.T., Sohn, D.H. 2008. Fatty acids ameliorate doxorubicin-induced intracellular calcium increase and apoptosis in rat cardiomyocytes. Biol. Pharm. Bull. 31, 809-815.

[59] Spanier, G., Xu, H., Xia, N., Tobias, S., Deng, S., Wojnowski, L., Forstermann, U., Li, H. 2009. Resveratrol reduces endothelial oxidative stress by modulating the gene expression of superoxide dismutase 1 (SOD1), gluthathione peroxidase 1 (GPX1) and NADPH oxidase subunit (NOX4). J. Physiol. Pharmacol.60, 111-116. 


\section{Figures}

A

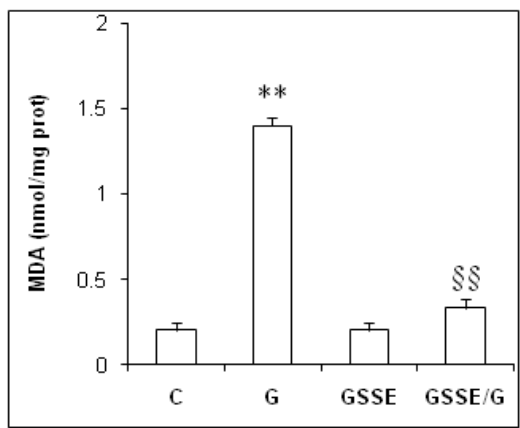

B

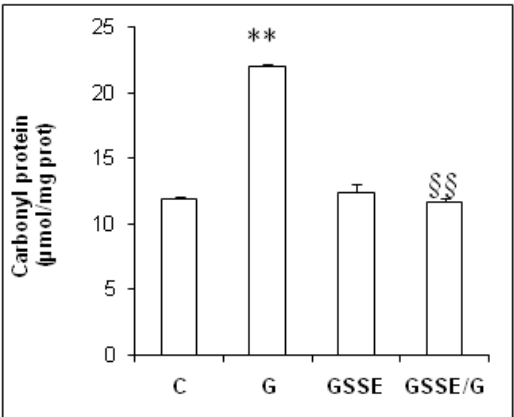

C

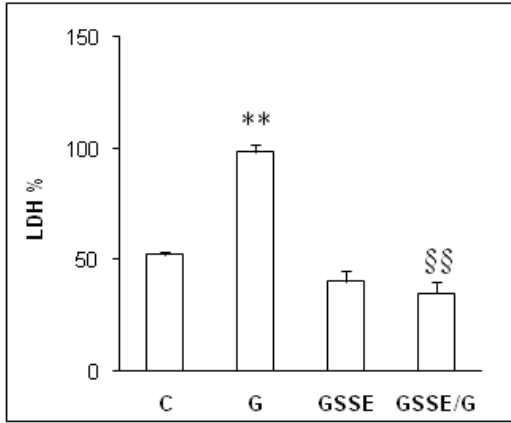

Figure 1: Effect of Grape Seed and Skin Extract on garlic-induced heart oxidative stress.

10\% ethanol (C), garlic (G), Grape Seed and Skin Extract (GSSE), or garlic plus Grape Seed and Skin Extract (GSSE/G) were administered to rats for 1 month, and heart lipoperoxidation (A), carbonylation (B) and LDH (C) determined. Results are expressed bymeans $\pm \operatorname{SEM}(n=10) .{ }^{* *} p<0.01$ vs $C ;{ }^{\S \S} p<0.01$ vs $G$. 
A

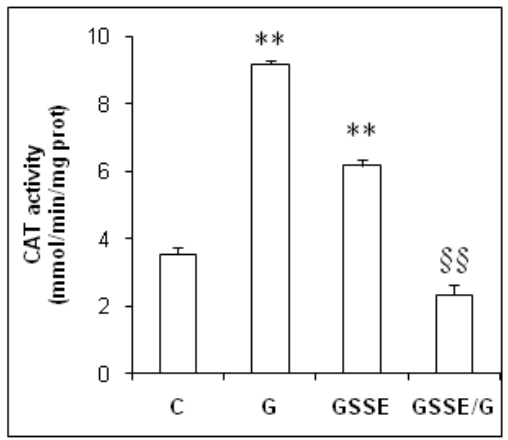

B

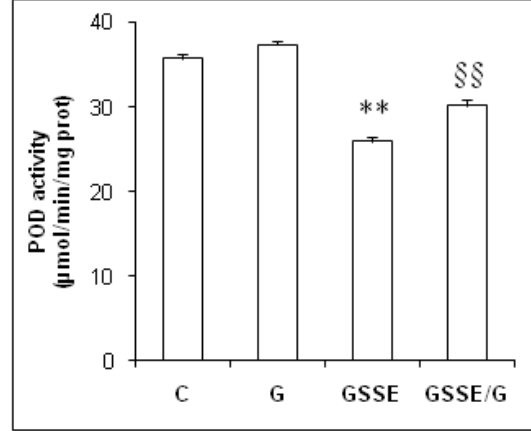

C

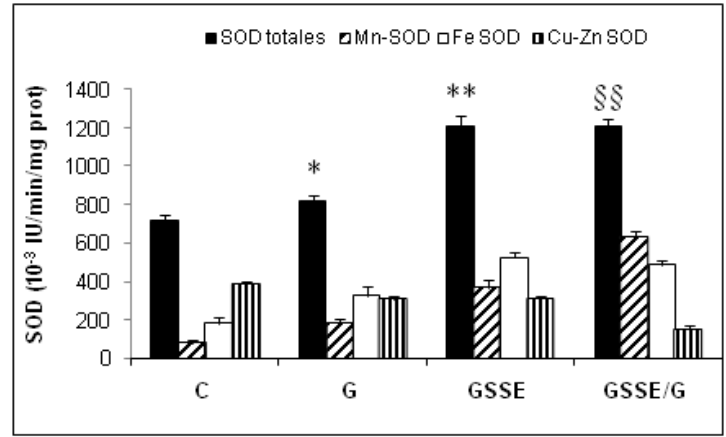

Figure 2: Effect of garlic and Grape Seed and Skin Extract on heart antioxidant enzyme activities.

Rats were daily administered with $10 \%$ ethanol (C), garlic (G), Grape Seed and Skin Extract (GSSE), or garlic plus Grape Seed and Skin Extract (GSSE/G) for 1month and catalase (A), peroxidase (B) and superoxide dismutase (C) activities determined. Results are expressed by means \pm SEM $(n=10)$. ${ }^{\star} p<0.05$ vs $C ;{ }^{\S} p<0.05$ vs $G ;{ }^{* *} p<0.01$ vs $C ;{ }^{\S \S} p<0.01$ vs $G$. 
A

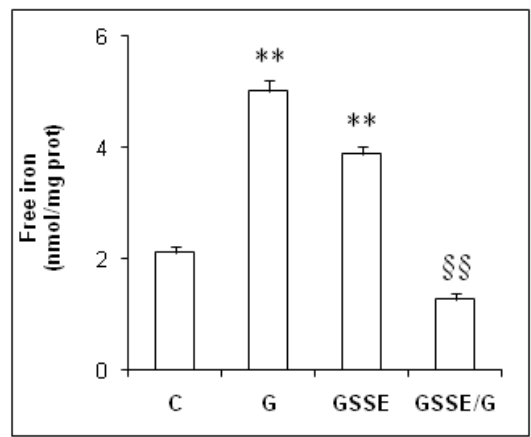

C

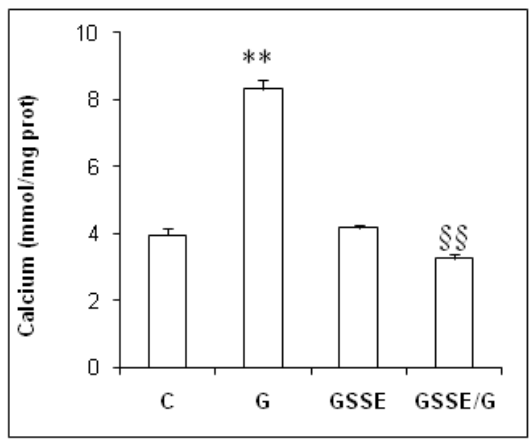

B

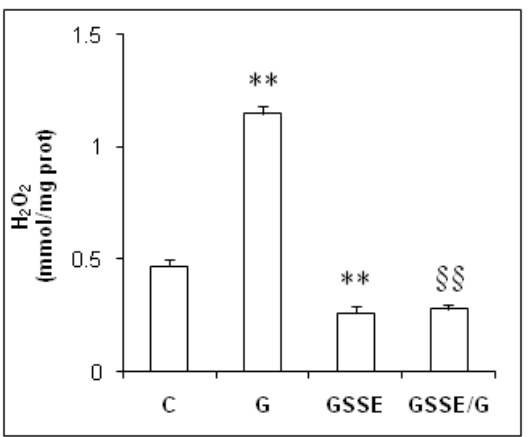

D

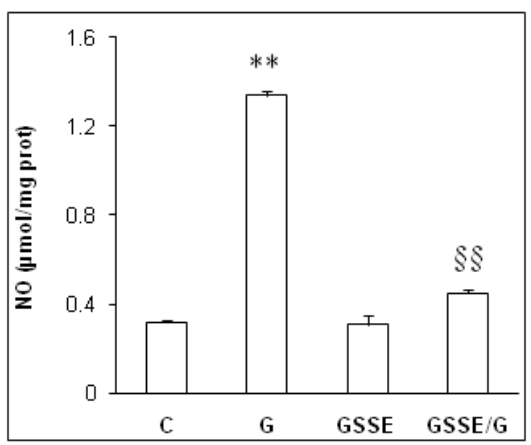

Figure 3: Effect of Grape Seed and Skin Extract on garlic-induced intracellular mediators.

Rats were daily administered with $10 \%$ ethanol (C), garlic (G), Grape Seed and Skin Extract (GSSE), or garlic plus Grape Seed and Skin Extract (GSSE/G) for 1 month and free iron (A), $\mathrm{H}_{2} \mathrm{O}_{2}(B)$, calcium (C) and NO levels (D) determined. Results are expressed as means $\pm \operatorname{SEM}(n=10)$. ${ }^{* *} p<0.01$ vs $C ;{ }^{\S \S} p<0.01$ vs $G$. 